\title{
A Research on Shipping Lines in Global Market
}

\author{
R.Srinivasan, S.Poongavanam, R.Vettriselvan, J.Rengamani, Fabian Andrew James
}

\begin{abstract}
The Shipping Lines, NVOCC, MTO's is a company that organizes shipments for individuals or other corporations and might too turn as a shipper. A forwarder is frequently not energetic as a shipper and turns merely as a manager, in other words as a third-party (non-asset-based) logistics provider that dispatches shipments via asset-based carriers and that books or otherwise arranges space for these shipments. The research study is about the factors influencing customer's choice of Shipping Lines Middle East Sector. So the researcher here used different descriptive methods like interview method, survey method and observation method to know the various impacts and expectation of the customers towards the customer's choice towards the shipping lines to Middle East Countries from Chennai.
\end{abstract} Ports

Key Words: Freight forwarders, Shipping lines, Middle east\&

\section{I.INTRODUCTION}

\section{History Of Shipping Lines}

The original function of the Lines was to arrange for the carriage of his customers' goods by contracting with various carriers. His responsibilities included advice on all documentation and customs requirements in the country of destination. His correspondent agent overseas looked after his customers' and kept him informed about matters that would affect movement of goods.

In modern times the Lines still carries out those same responsibilities for his client. He still operates either as a domestic carrier, or otherwise with a corresponding agent overseas or with his own company branch-office. In a single transaction, it can happen that the forwarder may be acting as a carrier (principal) or as an agent for his customer or both.

Document transfer fee/Document handover fee

International Freight Forwarders and NVOCCs and customs brokers often charge a fee for transferring documents to another transportation company at destination. This fee is a part of the ocean freight charges, being paid by the importer at the port of discharge in te incoterm FOB (Free On Board) and by the exporter at the origin in the incoterm CFR (Cost and Freight), CIF (Cost, Insurance and $F$ reight) there are many other Incoterms, those are the most common. This fee is separate from documentation fees charged by steamship carriers and NVOCCs as part of the freight charges on a bill of lading and is separate from other fees for document preparation or for release of cargo. Some companies may call this an admin fee, doc fee, doc transfer or other name but it exists in some form in most destinations around the world and is well known to most importers and exporters. Steamship carriers do not have this fee.

\section{SCOPE OF THE STUDY}

The study is all about the factors influencing customer's choice of shipping lines to Middle East from in and around Chennai. The study reviews the services offered by the Shipping Lines, NVOCC's, MTO's to their customers in various aspects of exports. So the researcher here approaches various Shipping Lines, NVOCC's, MTO's customers of different and studies their level of satisfaction and expectation that are gained. So the researcher here studies for the benefit of both customers and Shipping Lines, NVOCC's, MTO's in terms of satisfaction and good service respectively.

The methods of research study used by the researcher to observe in customer point of view are survey method, observation method and case study method. So the surveys can be done personally, telephonic and mail surveys. Observation can be done by structured and unstructured methods. So the researcher prepares a structural questionnaire format to understand customer's needs and expectation from the Shipping Lines, NVOCC's, MTO's in sending cargos.

So the researcher after reviewing the various customers about their impact and expectation he will observe the services offered by the Shipping Lines and gives a review to the Shipping Lines to know their strength and weakness in acting as an intermediate, by knowing the following facts

The Shipping Lines can access good services to their customers which will be much useful for their market growth and to retain the customers and to bring in more customers to their services.

So the researcher hereby says that the study is done for the favour of both customers and Shipping Lines, majority of this research is held for the purpose of the growth and diversification of the Shipping Lines.

Revised Manuscript Received on July 18, 2019.

Dr.R.Srinivasan, AMET Business School, AMET University, Chennai, Tamil Nadu, India.

Dr.S.Poongavanam, AMET Business School, AMET University, Chennai, Tamil Nadu, India.

Dr. R.Vettriselvan, AMET Business School, AMET University, Chennai, Tamil Nadu, India.

Dr. J.Rengamani, AMET Business School, AMET University, Chennai, Tamil Nadu, India.

Dr. Fabian Andrew James, AMET Business School, AMET University, Chennai, Tamil Nadu, India. 


\section{MIDDLE EAST}

\begin{tabular}{|c|c|c|c|}
\hline $\begin{array}{l}\text { Country } \\
\text { (Region) }\end{array}$ & Seaport & $\begin{array}{l}\text { Country } \\
\text { (Region) }\end{array}$ & Seaport \\
\hline Bahrain & Manama & Oman & Mina Qaboos \\
\hline Irak & $\begin{array}{l}\text { Basra } \\
\text { Um Qasr }\end{array}$ & Qatar & Doha \\
\hline Iran & $\begin{array}{l}\text { Bandar } \\
\text { Abbas } \\
\text { Bandar } \\
\text { Khomeini }\end{array}$ & $\begin{array}{l}\text { Saudi } \\
\text { Arabia }\end{array}$ & $\begin{array}{l}\text { Dammam } \\
\text { Jeddah } \\
\text { Jubail } \\
\text { Yanbu }\end{array}$ \\
\hline Israel & $\begin{array}{l}\text { Ashdod } \\
\text { Eilat } \\
\text { Haifa }\end{array}$ & Syria & $\begin{array}{l}\text { Lattakia } \\
\text { Tartous }\end{array}$ \\
\hline Jordan & Aqaba & Turkey & $\begin{array}{l}\text { Istanbul } \\
\text { (Port located } \\
\text { in Europe) } \\
\text { Izmir } \\
\text { Mersin }\end{array}$ \\
\hline Kuwait & $\begin{array}{l}\text { Shuaiba } \\
\text { Shuwaikh }\end{array}$ & $\begin{array}{l}\text { United Arab } \\
\text { Emirates }\end{array}$ & $\begin{array}{l}\text { Abu Dhabi } \\
\text { Dubai } \\
\text { Sharjah }\end{array}$ \\
\hline Lebanon & $\begin{array}{l}\text { Beirut } \\
\text { Tripoli }\end{array}$ & Yemen & $\begin{array}{l}\text { Aden } \\
\text { Hodeidah }\end{array}$ \\
\hline
\end{tabular}

\section{RESEARCH OBJECTIVES}

$>\quad$ To find how many Shipping Lines, NVOCC's, MTO's Operating in chennai

$>\quad$ To findhow many of them are having service to Middle East Ports

$>\quad$ To find how many of them carried cargo with a Market Share of more than 5\% and above

$>\quad$ To find the shipping lines who have less than $5 \%$ of Market share

$>\quad$ To analysis why these shipping lines have less than 5\% Market Share

\section{SOURCE AND TYPE OF DATA}

\section{Primary Data}

Primary figures involves in examination to gather unique statistics. It is regularly commenced next to the scientist grown some vision into the subject by gathering ancillary information. This can be through abundant forms, including surveys, direct statement and mobile discussions between others.

\section{Data Analysis}

The procedure of appraising statistics using investigative and analytical thinking to inspect each factor of the information delivered. This procedure of examination is just unique of the numerous ladders that necessity to be finished when showing a research testing. Information from numerous fonts is collected, studied, and then analyzed to form some sort of discovery or assumption. There are diversity of detailed information examination method, some of which include data mining, text analytics, business intelligence, and data visualizations

\section{Regression Analysis}

Regression analysis is a statistical instrument for the exploration of associations among variables. Typically, the agent pursues to establish the causal outcome of single variable upon another - the effect of a worth surge upon claim. To discover such subjects, the detective collects information on the fundamental variables of interest and pays regression to estimation the quantitative effect of the underlying variables upon the adjustable that they stimulus.

\section{Qualitative Data Analysis}

Qualitative investigation is much added particular than quantitative study and practices all changed approaches of gathering material, mainly individual, in-depth meetings and focus clusters. The nature of this type of research is exploratory and open-ended. Minor numbers of persons are questioned in-depth and/or a comparatively minor digit of focus groups are led. Members are questioned to reply to overall queries and the examiner or group mediator enquiries and discovers their reply to find and define publics' insights, sentiments and moods about the theme or clue being deliberated and to limit the grade of contract that

\section{LIMITATION OF THE STUDY \& RESULTS}

Descriptive studies can harvest annoying information that lead to significant references. On the other hand, descriptive research can be distorted by persons who do not appreciate its drive and restrictions. For example, one cannot attempt to attraction of decisions that display reason and consequence, since that is outside the limits of the data worked.

- The data collected from shipping lines which are operating from Chennai only.

- The opinion of the respondent may be subjective

- Time constraint

- High Cost

- Reliability of data

\section{LIST OF SHIPPING LINES, NVOCC, MTO IN CHENNAI}

* Adithya Lines Pvt Ltd.

* Aeromar Logistics Pvt Ltd. 


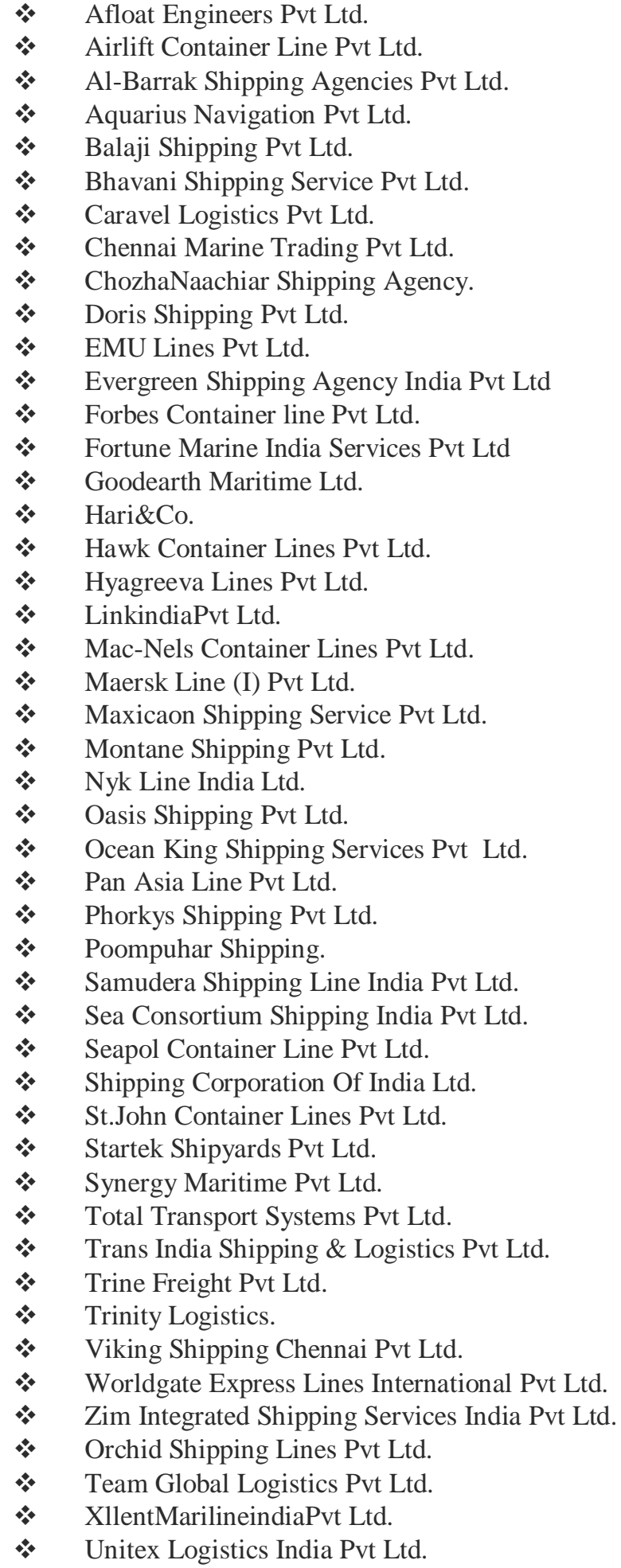

\section{CONCLUSION}

Now a days all the shipping Lines still carries sincerarily all theresponsibilities in favour of their client. Liners operates either as a domestic carrier/otherwise with some corresponding overseas agent/with their company branchoffice. In a single transaction, liners happen that the forwarder may be acting as a carrier (principal) or as an agent for his customer or on both.

\section{REFERENCES}

1. K.F. Yuen, J.M. Lim (2016). Barriers to the implementation of strategic corporate social responsibility in shipping, The Asian Journal of Shipping and Logistics, 32 (1), pp. 49-57

2. K.F. Yuen, X. Wang, Y.D. Wong, Q. Zhou (2017).Antecedents and outcomes of sustainable shipping practices: The integration of stakeholder and behavioural theories, Transportation Research Part E: Logistics and Transportation Review, 108, pp. 18-35

3. Park, C. (2016). "2020 Ship fuel regulation, shipping, shipbuilding business.

4. Lee, S. (2015). "DSME to launch the world's first LNG carrier container ship"..

5. Srinivasan, R., Poongavanam, S., Vettriselvan, R., Rengamani, J., James, F.A.(2019). Network optimization for distribution of south based OEM's passenger vehicles to other zones of India with reduced lead-time, International Journal of Innovative Technology and Exploring Engineering.

6. Srinivasan, R., Poongavanam, S., Divyaranjini, R.(2018) Wind turbine generator components-A study on transportation, International Journal of Mechanical Engineering and Technology.

7. Vettriselvan R., Ruben Anto., \& Jesu Rajan FSA (2018), Rural lighting for energy conservations and sustainable development, International Journal of Mechanical Engineering and Technology, 9(7):604611.

8. Vettriselvan R., Sathya M., \& Velmurugan T. (2018), Productivity and Profitability Mechanical Engineering Entrepreneurs: Business Perspective, International Journal of Mechanical Engineering and Technology, 9(8): 758-765. 